\title{
REFLECTION
}

\section{Why I Read}

David Young, PhD

220 Shipherd Circle, Oberlin, OH, USA.

$\mathrm{J}$ Gen Intern Med 24(3):434

DOI: $10.1007 / \mathrm{s} 11606-008-0818-3$

(c) Society of General Internal Medicine 2008

$\mathrm{R}$

eading a poem by Henry Vaughan

I raise my eyes to the ceiling breathe deeply in and out,

as if to thank whatever gods, once more,

for putting me into this world

where poems sometimes can sift words out of their daily sludge

to make them shine and sing.

Received July 28, 2008

Accepted September 11, 2008

Published online September 26, 2008 